\title{
Radical development nipped in the bud
}

\author{
Michael Ryan
}

The most exciting development in Soviet health care during 1988 was the appearance of fee charging units that functioned quite separately from the state run system. Emerging as a result of independent decisions by doctors and other health care personnel in the larger centres of population, these medical cooperatives represented private enterprise within the command economy. Although most patients thought highly of them, at the end of the year their activities were sharply curtailed or even ended by official decree.

The twin principles of cooperative ownership and self management had been legally sanctioned in a wide range of services and not only in health care. This endorsement of spontaneous individual initiative, which was implicit in the relevant legislation, ${ }^{1}$ should be seen as a recognition by the authorities of a familiar fact of life-namely, that public organisations were failing to supply many goods and services in the quantity and quality demanded. It is also a recognition of the extent of the black economy and an attempt to ensure that at least a proportion of this activity could be induced to assume legal (and hence controllable) forms. In the case of medicine the existence of concealed private practice is shown by the payments that many patients make to health care personnel for work which should be free of charge.

\section{...public organisations were failing to supply many goods and services in the quantity and quality demanded.}

At the same time the cooperatives were competing directly with publicly owned organisations for capital equipment and materials in a system where supply frequently proves to be inadequate and distribution is often inefficient.

\section{Cooperatives' shortcomings}

Such constraints help to explain two findings in a survey of 75 medical cooperatives functioning in 60 cities throughout the Soviet Union. ${ }^{2}$ As many as $69 \%$ reported a shortage of medical equipment and apparatus, only $6.4 \%$ had their own accommodation, while $56 \%$ complained of "absence of premises."

The problem of finding accommodation was often solved by using state hospitals and polyclinics at weekends or during the evenings when they would otherwise have been closed. The relevant legislation allowed individuals to choose whether to work in a cooperative as their main occupation or on a part time basis. It made sense to many doctors to do the latter in case official endorsement of the cooperatives was reversed. Only $10 \%$ of doctors surveyed were committed to practising primarily in cooperatives (the figure for Moscow was 5\%).

The survey also showed the range of specifically medical work undertaken by cooperatives. Gynaecologists were visited most frequently $(14 \cdot 6 \%)$, followed by neuropathologists $(7 \%)$, urologists $(7 \%)$,

\section{LiK: the first medical cooperative}

From its small scale beginnings in three rooms of a polyclinic this collective had expanded to the point where it comprised six outpatient departments together with two blocks for inpatient treatment. Surgeries were held by as many as 700 doctors whose numbers included individuals from the academic medical élite-members, and corresponding members of the USSR Academy of Medical Sciences. Patients could refer themselves directly to any specialist without a referral note or any other form of documentation. It was possible to ask for a home visit. The charge for a consultation had been set at 10 roubles (roughly £10).

Presumably responding to unmet demand, LiK provided (among other treatments) a range of services "for planning the young family." The cooperative's chairman and one of its cofounders, Dr V S Voronchenko, amplified that phrase by specifying "treatment of infertility, genetic consultation, the advice of a medical sexopathologist, gynaecological operations, and microabortions.'

and stomatologists $(6 \cdot 7 \%)$. Acupuncturists (4.9\%) were visited nearly twice as often as specialists in drug addiction $(2 \cdot 4 \%)$, who were bottom.

As the medical cooperative movement was unplanned a detailed account is unlikely to be found in a single source. The survey makes the point that "absence of statistical data for a large range of matters bearing on their activity complicates objective analysis of this phenomenon." But the term medical also embraced several collectives which offered a much needed home nursing or home help service or both. Though it is impossible to asses the size of this sector at the end of 1988, few collectives were operating as fully independent units of a kind analogous to private hospitals or clinics in the West.

One of the exceptions was the country's first unit in Moscow called LiK. (The word means image but here it is also an acronym for treatment and consultation.) When the cold wind of official disfavour had already started to blow a brief account of LiK appeared in Ogonyok, whose liberal and adventurous editorial policy has made it an intellectual flagship for perestroika. ${ }^{3} \mathrm{My}$ account is taken from that source (see box).

Accommodation is difficult to find in Moscow and in this connection $\mathrm{LiK}$ showed considerable business initiative. It concluded an agreement with the Izmailovo tourist agency for a package deal whereby a hotel room could be booked for three to 10 days together with full board (including dietetic meals), round the clock nursing, and consultations on the spot and in the cooperative's polyclinics-plus all the normal tourist entertainments.

At the same time LiK's leaders exploited the opportunities created by the law on cooperation by setting up a joint venture with an American corporation whereby treatment would be provided for foreigners and Soviet citizens who could pay in hard currencies. Medical equipment and instruments would be
SA2 8PP

Michael Ryan, PHD, lectur

BrMed F 1989;299:383-4 
purchased from abroad-obviously as a means of compensating for the shortages and low quality of home produced equivalents. Furthermore, exchange programmes would enable staff of the collective to have study leave in the United States while American doctors came to work in $\mathrm{LiK}$.

\section{For and against}

After its brief account $O$ gonyok printed a commentary that conveyed some sense of the cooperatives' exposed and hence weak position. The crux of the matter was an entrenched hostility on the part of many of the medical bureaucrats responsible for running the state financed health service. After long decades of state socialism the general sociocultural climate made it doctrinally difficult to endorse the idea of enterprise in the provision of medical care. This is consistent with the reported results of what seems to have been a large scale national survey. This found that just over half of the population expressed full approval for the creation of medical cooperatives, while only around $15 \%$ disapproved of the principle. In contrast the medical administrative-executive and managerial staff thought that only about a third of the population would be in favour, presumably reflecting their own presuppositions. As for rank and file doctors who did not participate in collectives, just over $40 \%$ totally supported them as being "important for society." A further $17 \%$ did not approve, taking the view that they diminished the commitment of doctors and nurses to their main professional activity. But only around $9 \%$ were categorically opposed for the ideological reason that individual and cooperative work "arouses private ownership interests."

Given that collectives and the state health system were competing for scarce resources, the success of the former depended to some extent on the cooperation of the latter over the prerequisites essential to the delivery of services. Asked about the desirability of the state units hiring out their premises, just over $65 \%$ of doctors were in favour and $20 \%$ against. These findings show support for peaceful coexistence between private enterprise and state provided medical care.

According to the chairman of Moscow's council of

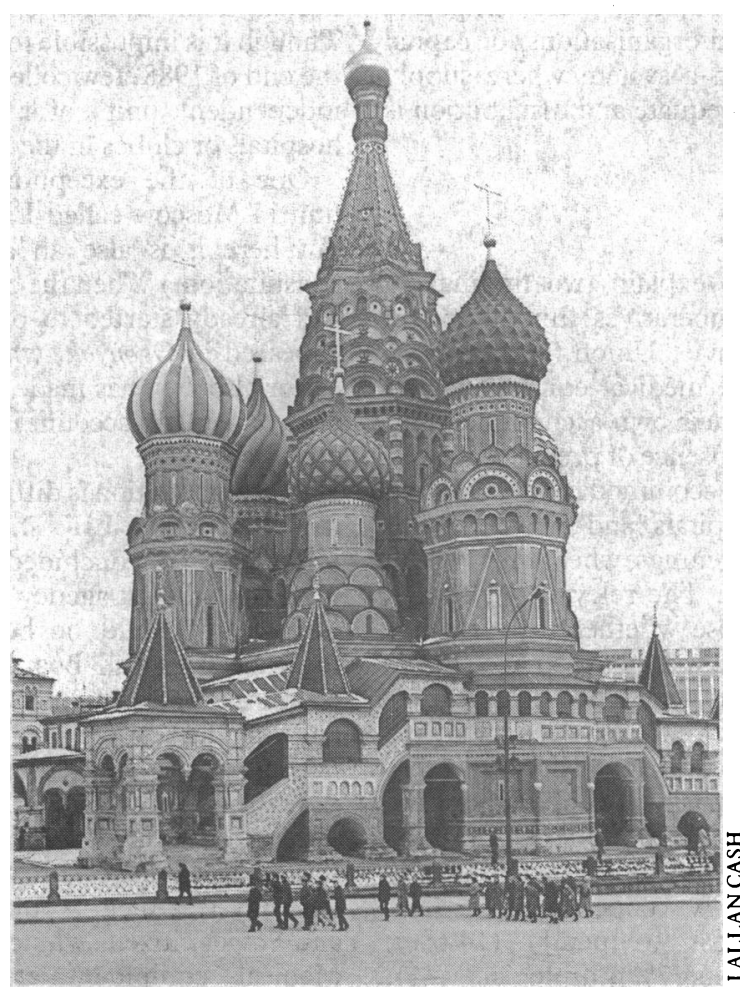

\section{Private care in the USSR}

It is simply impossible to make a comparison. . . I arrived here at 12 o'clock on a day which suited me. They did all the analyses at once and I had a consultation. I felt nothing at the time of the operation, no pain: they gave me an anaesthetic. I came round when I was already back in the ward and straightaway received attention. Now I'm going home. Tomorrow I'll return to work. I paid 70 roubles for everything and I have no regrets. In a polyclinic I would have had tests for a week and would have waited my turn for a week. In the hospital there would have been 10 people'on a ward, dirt, a single toilet for the entire floor; when you have the operation you wish that you had never been born. . . . And here I didn't hear a rough word. So are you saying that tomorrow there will be no such place? What will there be?

cooperatives of all types, nearly $99 \%$ of people who had been treated in medical cooperatives had a positive attitude towards them, as did almost $70 \%$ of people who had not made use of them. Among doctors who did not work in one, as many as $80 \%$ approved of them. Nevertheless, over $80 \%$ of the medical administrators were strongly opposed. ${ }^{+}$

\section{A coup de grace?}

The opening of hostilities occurred at the end of October 1988 with the issue of a statutory order from the USSR Ministry of Health. This order prohibited the hiring out to collectives of expensive equipment for diagnosis and treatment. Budget financed institutions should, of course, make more use of their own costly modern equipment, but surely that did not mean the banning of loan arrangements.

At the end of 1988 the state delivered a much heavier blow. A decree of the USSR Council of Ministers curtailed the range of services which different types of collectives could legally offer. This was tantamount to emasculation if not a sentence of death for some medical units since it prohibited, among other things, all obstetric work, invasive methods of investigation and treatment, and surgical intervention, including the termination of pregnancy.

A striking feature of contemporary Soviet policy, however, is that arbitrary seeming decisions by the government may evoke a powerful wave of indignation that finds expression in a relatively free press. Thus under the title "The cooperatives are closing" Ogonyok ran an article which complained that "no intelligible explanations" of the decree had been given and implied that, if patients had their way, the policy would change again.

That point is illustrated by the quotation from a woman who was asked to compare termination of pregnancy in an ordinary unit and in LiK (see box).

Comparable feelings of dismay were widespread, as is shown by the many letters that reached the editorial office of Ogonyok. These demanded that the relevant decree should be discussed at the next session of the USSR Supreme Soviet - that is, by the elected representatives of the people. ${ }^{6}$ If government policy towards medical cooperatives becomes less hostile it would mean the defeat of a powerfully entrenched bureaucracy by the force of public opinion.

1 Anonymous Zakon Soyuza Sovetskikh Sotsialisticheskikh Respublikh Ob individual noi trudovoi deyatel nosti. Provda 1986 noyabrya $21: 1,3$.

2 Shvyrkov G, Grishin V. Meditsinksie kooperativy: god pervyi. Argumenty i fakty 1989 yanvarya $14-20: 4$

3 Beletskaya V Novyi LiK meditsiny Ogonyok 1988:51:20-3.

4 Parkhomovskii E. Chto govoryat spetsialisty o novom postanovlenii po kooperatsii. Izvestiya 1989 yanvarya 19:2.

5 Anonymous. Sovet ministrov SSSR. Izvestiya 1988 dekabrya 31:2. 6 Salykova M. Kooperativy zakryvayutsya. Ogonyok 1989;8:15,25. 